$\xi=-1$ 圆

\title{
Region Housing Policies in Terms of its Social and Economic Security
}

\author{
Volodymyr Onyshchenko ${ }^{1}$, Anna Kozachenko ${ }^{2}$, Taina Zavora ${ }^{3 *}$

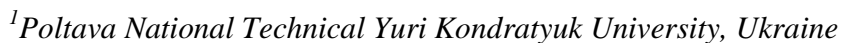 \\ ${ }^{2}$ Poltava National Technical Yuri Kondratyuk University, Ukraine \\ ${ }^{3}$ Poltava National Technical Yuri Kondratyuk University, Ukraine \\ *Corresponding Author E-Mail: Tainazavora@Gmail.Com
}

\begin{abstract}
The basics of the state housing policies formation are explored. Analysis of the housing policies formation directions in terms of transformational changes is conducted. Connection between economic and social spheres in the context of region social and economic security providing is substantiated. Special aspects of housing policies impact on region social and economic security formation are defined. Simulation of housing policies impact on region social and economic security is conducted. Integral estimation of housing policies is developed and its connection with some of the principal regional development social and economic indices is analyzed. Correlational relationships between the received housing policies integral estimation and such indices as household income, personal expenditures on goods and services purchasing, population income differentiation R/P 10\%, proportion of population with lower monthly income per capita than enacted living wages, correlation between monetary income of the most and the least haves $10 \%$ of population, and number of sicknesses. Dependence between people income from relative indices such as housing resources in average per capita and capital investment into house building is defined.
\end{abstract}

Keywords: house building, housing policies, housing policies integral estimation, housing resources, reconstruction, region social and economic security.

\section{Introduction}

Contemporary transformational changes in Ukraine are followed by economic and political instability increasing, social problems aggravation. According to households' survey data, concerning self-estimation of the level of their financial security and adequacy of return for meeting their primary needs, at the beginning of 2017 the major part of the population were revealed to be unsatisfied. Only $6.2 \%$ among 15033.4 respondents estimated their financial and material condition as sufficient, including for the purposes of saving. $44 \%$ were constantly denying themselves the essentials, excluding food. $4.9 \%$ were unable to provide themselves even with sufficient food. The biggest value for the respondents in order of importance became health, family, children, and material welfare. $41.5 \%$ mentioned investing into improving their living conditions in case of income increase [1]. Thus, decrease in the population standard of living, decline of its psychological and mental characteristics equate region social and economic security with the most important national issues, as an indispensable prerequisite for modern society progressive development.

The Constitution of Ukraine defines a man, his life and health, honor and dignity, inviolability and security as the highest social value. In this relation, formation and practical realization of the mechanism of providing region social and economic security require analyses of social policy effectiveness. Housing policy plays an important role in this process. Providing people with housing and creating secure living conditions request cautious housing policies forming and realization. In order to provide conditions for realizing citizens rights for housing according to the Constitution of Ukraine by means of increasing the amounts of housing construction, maintaining and reconstructing the current housing resources, providing stimulating factors to solve the housing problem, the state housing policy concept requires qualitatively new scientific substantiation

Thus, understanding peculiarities of housing policy influence on the region social and economic security will enable joining its separate elements and defining extend of its influence, and provide comprehensive vision of people security from risks and threats in the housing sphere.

\section{Problem Search}

Analysis of scientific works by Andrew Beer [2], T. Zayats, N. Yanevych [3], N. Trusova, P. Klymenko [4], O. Tinkova, S. Tinkov [5], S. Plagerson [6], O. Illyash [7], O. Komelina, N. Fursova [8], V. Kharabara [9], as well as our own research enabled us to offer methodological approach to region social security estimation; to formulate theoretical and methodological approaches to diagnose the level of region social security; to define methodological basics of region housing policies creating; to develop methodological recommendations as for housing policies forming at the regional level in the direction of housing construction; to substantiate the necessity of creating regional programs for providing people with affordable and social housing $[10-11]$.

In terms of transformational changes, housing policies creating requires conducting analysis of housing construction development and housing resources reconstruction. As a result of the research carried on, special aspects of housing policies influence on region social and economic security formation are defined. There is a 
necessity of conducting integral estimation of housing policies condition and analyzing its connection with major social and economic indices of regional development.

To reach the primary goal the following combination of general scientific and special research methods were used: abstractional and logical aimed at theoretical generalization and framework of categories research; system-oriented analysis (in the process of analyzing conditions for social and economic indices and indicators of region social and economic security); expert survey aimed at revealing real and potential threats in Poltava region housing sector; monitoring, comparative method, economic and mathematical methods used while evaluating Poltava region housing recourses; graphical method used for research results visual displaying; statistical method used for region social and economic security indices evaluating.

Contemporary regional housing policies is being formed taking into account state housing policies, and it is an integral constituent of Ukraine social and economic policy aimed at increasing its citizens well-being. Region's housing policies creation is conducted accordingly to interrelated principal directions of citizens housing needs realization. Together with these directions realization it involves legislative, social, organizational and economical, architectural and constructional, exploitation and technological measures with account of the region of realization (fig. 1) resource, workforce and financial potential [12, 13]. The principal aims and objectives of the housing policies of Ukraine are embodied in the Conception of the state housing policies approved by the Verchovna Rada ordinance on 30.06.1995 № 254/95-VR. The state housing concept defines the factors causing housing policies reforming, major directions and ways of its realization.

Inconsistencies of reforming different spheres of economy, lack of a clear development strategy have lead to the state policy measures ineffectiveness. Special aspect of housing policies formation in the context of providing the region social and economic security includes the necessity of taking into account social and economic changes in the state, citizens' need in obtaining social housing, purchasing and construction affordable and commercial housing and its maintenance.

Region's social and economic security consists in its ability to resist inside and outside factors of destabilizing social and economic situation and appears in providing possibilities for free economic activity of business entities and guaranteeing the population social development. A region is an object of social and economic security, and a person is its subject. Due to this, social and economic security provision consists in preserving, accrual and balancing of the region's social, nature and resources and ecological potential. Regional policy is a defining instrument of reaching the aims and solving problems of a region's social and economic security. The principal criteria of region's social and economic security include: social consumption norms, quality and standard of peoples' living, indicators of the environment, indices of region's economic development and investment attractiveness etc.

Research of the region's housing policies under providing its social and economic security is defined to be the principle of rights and freedoms priorities of a person and a citizen. Prioritized social interests include: provision of the peoples' standard of living constant increase; middle class formation and establishment, overcoming poverty; liquidation of social inequality, sharp population stratification; providing the population social protection, a person's targeted care; improving the population's health condition, providing healthcare in the workplace and at home. Separate group is made up of social interests in the labor sphere: preserving and developing of the population highly productive laboring and intellectual potential; increasing working population laboring, commercial and innovative activity.

Development of social infrastructure, development of the system of education and health care, improvement of housing conditions are aimed at increasing the level and the quality of the life of population. Achieving the state of region's social and economic security does not mean total liquidation of all the threats, as far as they are constantly generated by the dialectic of society development.

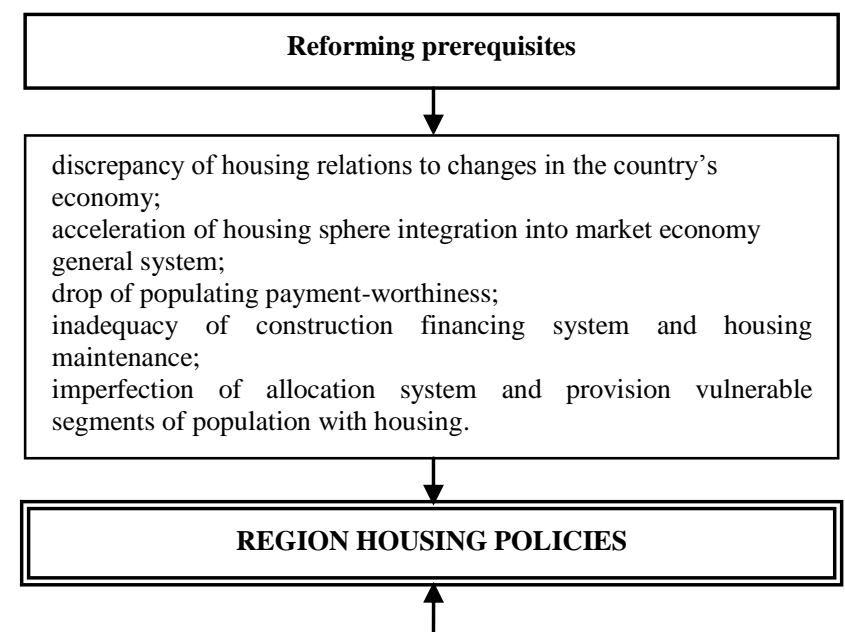

Basic concept of the region housing policies on the ground of J. Tinbergen theory

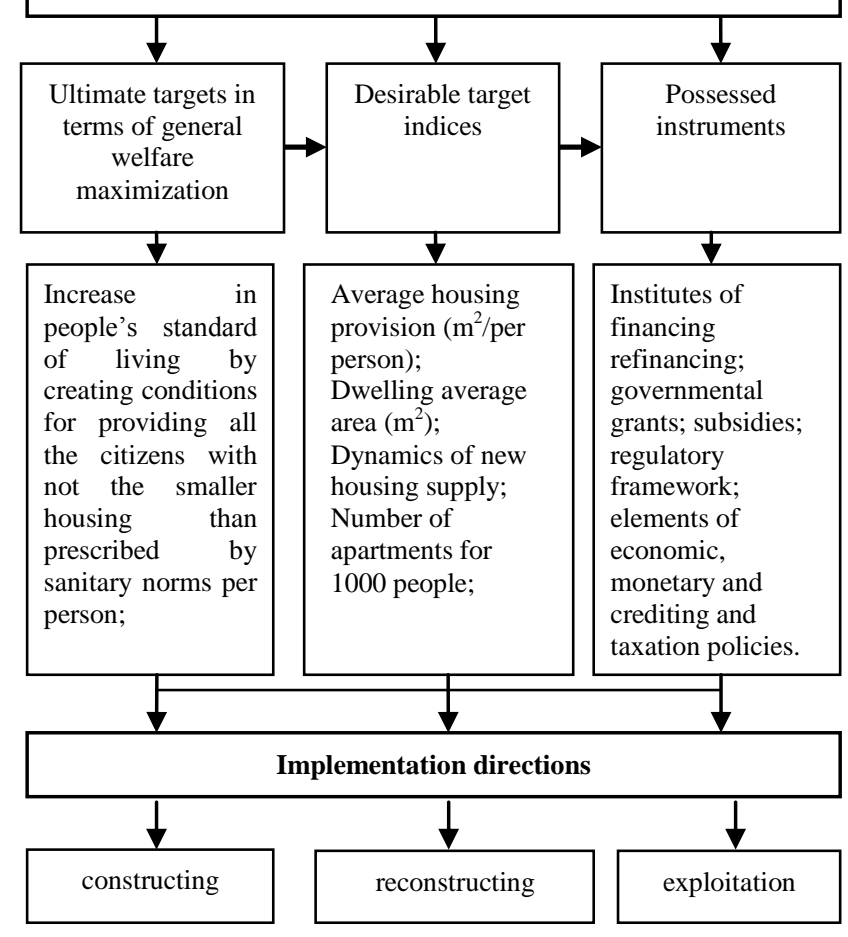

Fig. 1: Conceptual foundations of region housing policies

That is why let us consider that social and economic security is a result of effective social and economic policy which has to precaution society from fallouts, outpouring of conflict situations, and contribute to increasing its population welfare.

According to general classification of threats to social and economic security of the region, they are divided into inside and outside ones. Constituents of inside and outside threats to social and economic security of the region, altogether with their identity on the state region can have regional specific features, which in turn require direct regional policy formation. The most important threats to social and economic security remain poverty of the population, sharp stratification and increase in social inequality in the society. Poverty is characterized by inability, due to the insufficient funds, to keep quality level of life, to get quality health caring services, educational services, to have defined at the legislative level sanitary norms and living conditions. 
Lack of housing and its insufficient condition is one of the reasons causing negative demographic situation in the country, due to which providing citizens with qualitative housing that meets technical, sanitary and esthetical requirements is the most actual social problem, which in case of its solving would contribute to region social and economic security ensuring.

Housing resources formation is made in the following way: new housing construction and taking it into use; existing housing reconstruction together with re-equipment of non-residential premises into residential ones; reshuffling non-residential premises into residential ones; transferring a part of residential premises in the newly-constructed residential buildings into the territorial communities ownership by property developer; transferring social housing constructed at expense of the state budget funds from state property into communal one [4, 14].

Principal direction of housing resources formation is housing construction (fig. 2).

Construction of general purpose housing resources is conducted both at citizens own expense and by using existent funding model of construction financing (banking, subsidized and corporate).

\begin{tabular}{|c|c|c|}
\hline \multicolumn{3}{|c|}{ HOUSING } \\
\hline Commercial & Affordable & Social \\
\hline $\begin{array}{l}\text { housing with } \\
\text { statutory lower } \\
\text { and not statutory } \\
\text { upper limitations } \\
\text { of apartments } \\
\text { areas, and } \\
\text { detached houses, } \\
\text { which provide } \\
\text { level of comfort } \\
\text { living not lower } \\
\text { than minimal } \\
\text { permissible (DBN } \\
\text { V.2.2-15-2005, } \\
\text { attachment B) }\end{array}$ & $\begin{array}{l}\text { inexpensive housing } \\
\text { which can afford } \\
\text { citizens with low } \\
\text { income level which } \\
\text { require improving } \\
\text { their housing } \\
\text { conditions (Descree } \\
\text { of the President of } \\
\text { Ukraine } \\
\text { № } 077 / 2007 \text { )- } \\
\text { housing with the } \\
\text { area limitations not } \\
\text { lower than minimal }\end{array}$ & $\begin{array}{l}\text { housing with } \\
\text { statutory lower and } \\
\text { upper limitations } \\
\text { of apartments } \\
\text { areas and } \\
\text { dormitories rooms } \\
\text { according to the } \\
\text { existing sanitary } \\
\text { norms providing } \\
\text { minimal } \\
\text { permissible level } \\
\text { of comfort living } \\
\text { (DBN V.2.2-15- } \\
\text { 2005, attachment } \\
\text { B) }\end{array}$ \\
\hline
\end{tabular}

Fig. 2: Classification of housing according to the normative documents

To provide socially vulnerable group of population with housing there should be available housing resource of social and special purpose. Legal, organizational and social fundamentals of state policy towards social housing providing are defined by the Law of Ukraine "About housing resources of social purpose". Characteristic feature of social housing is that it cannot be privatized, sold, bought-out or underleased, and is provided for citizens whose annual monthly gross income for the previous year calculated per a person is less than amount of averaged housing renting price in the given residential place and minimum subsistence level fixed by the government. While calculating annual monthly gross income the value of property is included, which has been and still is in the citizen's and the members of his family ownership for the last five years, that precede the year of registering for social housing. Altogether, the lack of current statistic data as for existence of a queue for obtaining such housing in Ukraine as well as housing itself has to be noted.

Housing resource of special purpose performs specific functions. It includes service housing, dormitories, comprising special ones premises for temporary housing; family-type children's homes; shelter-care hotels; temporary housing premises.

Affordable housing construction remains important in Ukraine taking into consideration housing demand. Constructing of affordable housing aimed at citizens with average, lower than average and higher than average incomes, includes using citizens' own funds, attracting loans, state support and providing accommodations on lease with rant charge paying and with the following buying-out. A specific feature of affordable housing as opposed to social one is its transfer into being privately-owned, which is a motivation for saving and attracting people's funds, and mortgage development.

The process of region housing policies formation consists in defining elements of housing policies qualitatively new essence in the course of social and economic system evolution. Integrity of economic and social spheres appears in reproductive aspect of their connection. Thus economy development contributes to population standard of living improvement through services availability in such spheres as education and health care. Increase in people's welfare and growth of the middle class share in its turn influence the development of economy and national wealth.

Housing construction enlargement is one of the directions of citizens' right for housing realization. Major construction as a branch of material production includes project and research, scientific and research, constructing and assembling organizations, enterprises of constructing industry, building materials manufacturing and transport. Other branches of national economy are also involved in the sphere of capital construction, providing it with metal and metalwork, concrete, timber, fuel and energy resources.

It is proved that construction is one of the best economy multipliers. According to specialists calculating, every hryvnya invested in construction adds more than two hryvnias into GDP increase, every additional working place in constructing sphere provides five-six workers of other spheres of economy with work. Housing construction has the most significant multiplying effect. Thus, more than 70 industries supply it with resources, materials, and engineering structures. There are more than 3,5 unities of investment into other sectors of national economy per one unity of investment into housing construction, its maintenance and reconstruction.

In its turn, scales, speed and structure of fund investment in the system of Ukraine housing policies providing are means of change of manufacturing ratios, creating new and reorienting existing enterprises, development of production facilities, and enables ensuring of construction products competitiveness. Improvement in capital investment technological structure in the fixed assets and their division between the main constituents, in particular increase in the capital investment ratio of expenses for purchasing main production funds active part contributes to public production effectiveness increase.

Housing constructing has its characteristic features which require the necessity of incorporating various forms of organizing a managing the construction process, namely; variety of construction participants, uniqueness of construction objects, and relative slowness of capital turnover, high investment risk level. These peculiarities influence housing construction organizing and construction market functioning.

Main sources of investment into housing construction include budget, private, borrowed and attracted funds. State budget is a significant source of housing construction financing. For instance, state investment ratio in developed countries is equal to $40 \%$. From 1990 in Ukraine a share of state investment reduced, which lead to slowing the pace of capital fund renewal. The highest ration in the structure of investment into capital fund according to the funding sources in 2017 belonged to enterprises and organizations own funds $-69.9 \%$.

The highest capital investment ratio in 2017 is disbursed in Dnipropetrovsk $(9.8 \%)$, Kyiv $(7.5 \%)$, Lviv $(5.4 \%)$, Donetsk (3.8\%) and Poltava (3.7\%) regions [15].

It is fair to set aside influence of housing construction on labor market functioning. At the beginning of 2017 in Poltava region 16.7 thousand people were involved in the constructing works. The number of registered jobless was 718 while employers required 96 employees for filling specific constructional occupations. There is an increase in demand for a range of constructional occupations in the region as well as at the level of common state labor market tendencies; others on the contrary 
require it. In turn, training of advanced specialists requires educational establishments for providing quality education.

Taking into account social factors, in particular the necessity of providing population with housing and decent living conditions, require further housing construction development which in turn is a source of economic development. Accordingly, analysis of economic and social spheres interrelation traits serves as a foundation for defining a list of integral system indices for evaluating region social and economic security.

At present housing resources of Ukraine makes approximately 20 per cent of the state capital funds value, its preserving is an important mission of the state housing policies. At the beginning of 2017 Poltava region housing resources were equal to 36151.5 square meters of the total area which is $0.5 \%$ lass comparing to 2000. Analysis of the region housing resources and providing population with housing revealed the following tendencies:

- decrease in housing resources area from 2005 to 36151.5 square meters of the total area at the beginning of 2017;

- increase in rural housing resources with simultaneous decrease of the urban one starting from 2011 to 2017;

- increase of population housing provision index, in average per capita, square meters;

- increase in houses qualified as old housing stock from 1683 in 2010 to 2756 in 2010 ;

- growth in amount of failing housing stock from 453 houses with total area of 21113 square meters in 2010 to 1180 houses with total area of 52433 square meters at the beginning of 2017 [16].

Analysis of indices characterizing housing policies conditions revealed their considerable differentiation in terms of regions. Resolution of the Cabinet of Ministers "On the Establishment of State Social Standards In the Area of Housing and Communal Services” № 409 established statutory indicator of total housing area provision equal to 21 square meter per person. The analysis results revealed that in Poltava region 3936 families live in failed or old housing stock. That is why it is important to understand the meaning of "average provision with total housing area" index, because statistical data contain information about the amount of population living in condition with provision index lower than sanitary standards which is 13.8 square meters. At the same time it is lawful to note the lack of the recent statistical data concerning accommodation waiting list, which can define the need in social housing.

Lack of housing and its unsatisfactory condition is one of the reasons causing negative demographic situation in the country, due to which providing citizens with qualitative housing that meets technical, sanitary and esthetical requirements is the most actual social problem, which in case of its solving would contribute to region social and economic security ensuring.

Solving the problem of housing provision is complicated with unsatisfactory technical condition and low quality of pre-war and post-war housing as well as housing constructed in 1950s-70s according to the projects of the first mass series of big-panel, modular and brick houses. That is why analysis of available housing resources according the years of construction has an important value in the region housing policies formation and ensuring its population social and economic security. While analyzing housing resources, class of building defined in accordance with Unified dwelling classifier has a significant importance, which characterizes housing quality and availability of technical equipment, and its maintenance is reached by major repairs conducting.

Research results performed by analytical center of Ukrainian towns association point up the fact that in our country there are 25.5 thousand of residential buildings constructed according to projects of the first mass series of big-panel, modular and brick houses with total area equal to $72 \mathrm{mln}$ square meters, which means that $23 \%$ of urban housing resources require reconstruction and modernization. Almost every fourth town dweller lives in residential houses that depleted their life cycle and are in unsatisfactory technical condition.
Considerable wear and tear of the first mass series residential houses, their energy efficiency and comfort low level is a reason for conducting capital repairs, reconstruction, modernizations of housing premises using advanced materials, equipment and energy efficiency technologies.

Reconstruction of housing in the way it is conducted these days (heat insulation of faces, addition of mansard roofs, extension of window bays and filling pieces etc.) solves only local energy efficiency tasks, enlarging areas of some accommodations. It does not create significant addition in number of accommodations for those waiting in a line and for commercial purposes. Investment flow into new housing construction and investing into housing resources reconstruction is aimed at meeting private objectives, which do not provide solving major tasks, i.e. intensive housing addition for population and preserving available housing resources by prolonging reconstructed houses life cycles and transforming urban development infrastructure.

Housing resources reconstruction is conducted in the following directions: capital repairing, modernization, demolishing.

Legal, economic, social and organizational foundations of conducting complex residential area reconstruction with replacing obsolete residential and nonresidential resources are defined by the Law of Ukraine "On the Complex Reconstruction of Residential Area of Obsolete Housing Resources". It is regrettable to state the lack of complex reconstruction in residential areas of old housing resources. The process of residential buildings reconstruction is complicated with the need in hundred thousand families mass resettlement from the houses, which in turn, in accordance with existing at present social construction norms, requires 1,5 times more housing than it is available.

At the same time it is necessary to realize that exploitation of the first mass series residential houses up to their complete deterioration can lead to social catastrophe in each of the regions. Advantages of investing into housing reconstruction include possibility of living space further construction, which can be used as a commercial resource for expenses covering; it involves availability of both land plot and utilities for housing resources maintenance and developed social infrastructure. Altogether the necessity of proper examination and expertise of a residential house should be taken into account, which requires financial resources; amount of research and expertise works will take a long time. Thus, worsening of housing resources condition and quality of housing and communal services leads to aggravation of social risks and decrease in conditions of population of Ukraine social security. Under such conditions, housing policies formation has to be conducted on the basis on energy saving and energy efficiency. An important place belongs to defining social and economic basics of housing resources thermal modernization.

Process of housing resources thermal modernization requires legislation improving taking into consideration the experience of the leading countries of the world in organizing and conducting rehabilitation of the housing resources. We find it necessary to develop a work flow chart at the regional level, which would include stages of performing residential houses thermal modernization, legal and organizational aspects, institutional and financial supply. In terms of decentralizations an important stage is inventory check of available housing resources and evaluation of its condition.

Inventory of Poltava region housing resources condition revealed that the biggest ration in the region housing resources structure according to the years of construction belongs to the one put into service in 1946-1960 (25.7\%). Housing resources constructed in 1961-1970 is next according to size. Here should be noted the availability of housing resources constructed before 1919, a share of which makes more than $4 \%$. At the beginning of $2017,175.5$ thousand square meters of total housing premises area out of 36151.5 thousand square meters total housing in Poltava region, were in state of disrepair [16]. Due to findings of experts from the Ministry of Regional Development, Building and Housing of Ukraine, more than $90 \%$ of all the high-rise buildings require thermal modernization. In turn it should be acknowledged that 
housing resources thermal modernization needs considerable financial investments.

An issue of the state energy security balanced system formation and taking the country to the new level of energy sufficiency define the priorities of housing resources energy saving and energy efficiency directions [10, 17]. Study of Poltava region population attitude to the social and economic processes, in particular to implementing measures on housing resources energy efficiency and energy saving enabled revealing sticking points of the process. They include absence of the biggest part of respondents' financial abilities and motivation due to the possibility of obtaining subsidies, the population low level income, backdated wages, and unwillingness to execute lease relationships while renting an apartment.

Thus, in accordance with different experts findings, increase in residential buildings energy efficiency will enable to decrease exploitation energy expenses in the housing sector $2.0-2.5$ times approximately.

It is defined that the main energy saving potential is concentrated in consumer's hands (up to 45\%), its realization is possible by means of energy saving measures implementation at the stage of heat consuming. Energy saving measures implementation and houses capital repairing require quite big funds, payback time of which is from 8 to 15 years.

Forming financing sources for energy efficiency measures is a basis of energy saving housing policies successful realization. Projects on energy efficiency increase may be financed using various mechanisms and form different sources. That is why an important role in this process belongs to agreed course of actions at least on the regional level and developing infrastructure elements, such as information and consultation energy savings centers.

With the aim of increasing efficiency of fuel and energy resources using and strengthening national economy competitiveness, in Ukraine The State Target Economic Program of Energy Efficiency and Developing the Sphere of Producing Energy Products from Renewable Sources of Energy and Alternative Fuels for 2010 2010 has been approved. In 2016 there were $900 \mathrm{mln}$ hryvnias and in 2017 - $800 \mathrm{mln}$ hryvnias allocated for "warm loans" program realization. In such a way for the first time in many years in Ukraine the state offered the society European approaches to energy saving programs realization, in particular a program on houses heat insulation, according to which the state refunds a part of a loan amount spent for energy effective equipment and materials for the population, condominium association and housing association (from 20 to $70 \%$ ).

In 2017 gas consumption was reduced by 6 billion cubic meters in the three categories of consumers (population, district heating companies and budget sphere) comparing to 2014. As a result, in $2017 € 1,2$ billion was not spent for imported gas purchasing. For the fourth year in a row in Ukraine local programs of "warm loans" cheapening are being introduced. At the beginning of 2018 107 local programs of the population and condominium association additional support while conducting houses heat insulating were applied. It is 23\% more than in February 2017, when there wer only 81 such programs. Local authorities have also became more intense in increasing these programs financing. In $2018115 \mathrm{mln}$ hryvnias were allocated for local programs implementation, which is $28 \%$ more comparing to the same period in 2017. At that time sum of financing was equal to $82 \mathrm{mln}$ hryvnias.

Starting from February 2-nd 2018, any individual having access to residential building in Ukraine and willing to increase its energy effectiveness can also use IQ Energy Program, developed by the European Bank for Reconstruction and Development (EBRD). IQ Energy Program is a program for promoting improvements in the sphere of Ukraine housing sector energy efficiency in accordance with European energy efficiency standards.

Thus, state policy in the sphere of buildings energy efficiency provision should by based on the following foundations: provision of buildings energy efficiency necessary level according to technical regulations, state standards, norms and rules; implementation stimulating to lessen energy resources consumption in the buildings; creating conditions for attracting investments aiming implementation measures for providing (increasing the level) of buildings energy efficiency and thermal modernization.

Due to this government bodies with the aim of increasing housing policies measures effectiveness in the context of the region social and economic security provision should define housing policies ultimate targets and having evaluated political instruments, to define target indicators, which they are willing to reach. The ultimate aim of housing policies at both state and regional levels is improvement of population standard of living by creating conditions for providing all the citizens with housing to the extend which would not be lower than it is defined by the sanitary norms per person.

The analyzed condition of housing policies in the directions of its formation enabled us to perform modeling of its influence on the region social and economic security. Due to this we have offered the methods of housing policies conditions integral estimation and defined the connection between the grade obtained with the main regional development social and economic indices.

Basic indicators for integral estimation are chosen the following ones:

1) total area of housing accepted into service over the year, thousand of $\mathrm{m}^{2}$;

2) housing resources in average per citizen, $\mathrm{m}^{2}$;

3 ) number of apartments constructed over the year, thousand;

4) capital investment into housing construction, thousand of hryvnias.

These indices are denoted by $\mathrm{x}_{1}, \mathrm{x}_{2}, \mathrm{x}_{3}, \mathrm{x}_{4}$ accordingly. Value of $\mathrm{i}$-indicator in $\mathrm{t}$-year is denoted by $\mathrm{x}_{\mathrm{i}}(\mathrm{t})$. To combine these indicators in common integral estimation it is necessary to define the relative relevant indicators. Such indicators are calculated from the equation

$$
y_{i}(t)=1+\frac{x_{i}(t)-x_{i}^{\min }}{x_{i}^{\max }-x_{i}^{\min }},
$$

where $y_{i}$ is a relative index of housing policies estimating; $y_{i} \quad(t)$ is value of i-indicator in t-year; $x_{i}^{\max }=\max _{t} x_{i}(t)$ is the biggest value of $\mathrm{x}_{\mathrm{i}}(\mathrm{t})$ indicator over the time of conducting research;

$x_{i}^{\min }=\min _{t} x_{i}(t)$ is the smallest value of $\mathrm{x}_{\mathrm{i}}(\mathrm{t})$ indicator over the time of conducting research.

Relative indicators defined in such a way are within the limits from one to two.

Integral indicator for housing policies estimation on the regional level is defined from the equation

$$
W=\sum_{i=1}^{4} a_{i} y_{i},
$$

where $\alpha_{i}$ is indicators weighted coefficients. These coefficients are defined by the method of modified major component, with covariance matrix of $y_{i}$ indices built for it. This matrix looks like this:

$$
K=\left(\begin{array}{cccc}
0.0874 & 0.0076 & 0.0797 & 0.0167 \\
0.0076 & 0.0962 & -0.0070 & 0.0849 \\
0.0797 & -0.0070 & 0.0920 & 0.0131 \\
0.0167 & 0.0849 & 0.0131 & 0.0955
\end{array}\right)
$$

At the following stage of integral estimation of housing policies condition let us calculate eigen values and corresponding eigen vectors of this matrix. Eigen vector corresponding to the biggest eigen value of covariance matrix looks like this 


$$
V=\left(\begin{array}{c}
0.431 \\
0.545 \\
0.3853 \\
0.6072
\end{array}\right)
$$

Weighted $\alpha_{\mathrm{i}}$ coefficients are proportional to this vector component squares, i.e. $\alpha_{1}=0.1858, \alpha_{1}=0.2970, \alpha_{1}=0.1485, \alpha_{1}=0.3687$.

Integral estimation value of Poltava region housing policies in given in the table 1 .

Table 1: Dynamics of housing policies integral estimation

\begin{tabular}{|l|c|c|c|c|c|c|c|}
\hline Years & 2011 & 2012 & 2013 & 2014 & 2015 & 2016 & 2017 \\
\hline $\begin{array}{c}\text { Housing } \\
\text { policies } \\
\text { integral } \\
\text { estimation }\end{array}$ & & & & & & & \\
& 1.4588 & 1.5292 & 1.6586 & 1.5927 & 1.9911 & 1.6112 & 1.7826 \\
\hline
\end{tabular}

To reveal specific aspects of housing policies influence on the region social and economic security we defined the correlation connectivity between the obtained housing policies integral estimation and some indices of the region social and economic development. For each of these indices characterizing social and economic development the correlation coefficient between it and housing policies integral estimation was defined. We test the coefficients obtained for relevance by t-criterion. The list of social and economic development indices for which correlation connection with housing policies integral estimation is defined, is given in Table 2.

Table 2: Analysis of social and economic development indices dependence on housing policies integral estimation

\begin{tabular}{|l|c|}
\hline \multicolumn{1}{|c|}{ Index of social and economic development } & $\begin{array}{c}\text { Coefficient of } \\
\text { correlation with } \\
\text { housing policies } \\
\text { integral estimation }\end{array}$ \\
\hline Population incomes & 0.660 \\
\hline $\begin{array}{l}\text { Population expenses on purchasing goods and } \\
\text { services }\end{array}$ & 0.837 \\
\hline Population income differentiation R/P 10\% & -0.756 \\
\hline $\begin{array}{l}\text { Proportion of population with lower monthly } \\
\text { income per capita than enacted living wages }\end{array}$ & -0.803 \\
\hline $\begin{array}{l}\text { Correlation between monetary income of the most } \\
\text { and the least haves 10\% of population }\end{array}$ & -0.606 \\
\hline Sicknesses amount & -0.822 \\
\hline
\end{tabular}

Thus modeling of housing policies influence on the region social and economic security enabled revealing the connection between housing policies integral estimation and main indices of the region social and economic development (fig. $3-6$ ) [18 - 20].

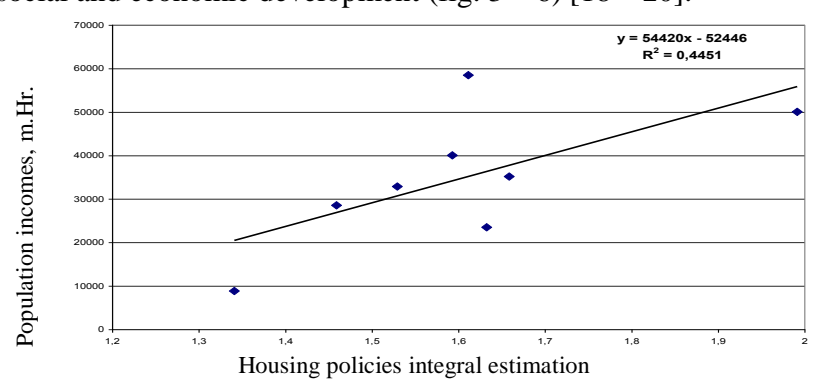

Fig. 3: Dependence of population expenses for purchasing goods and services on housing policies integral estimation

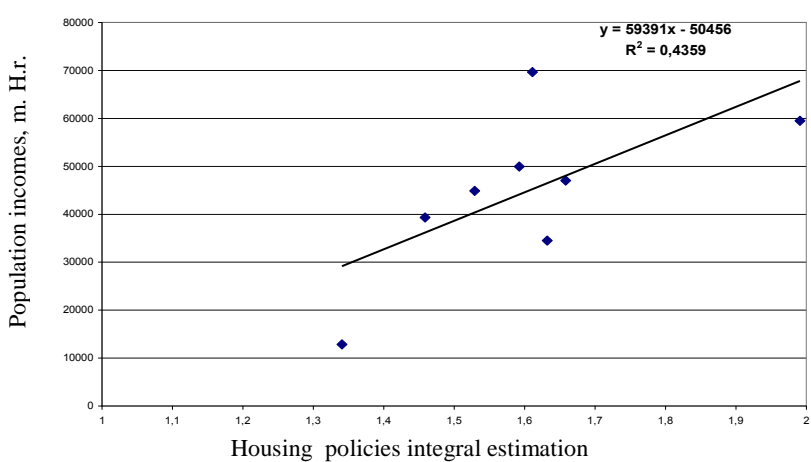

Fig. 4: Dependence of population incomes on housing policies integral estimation

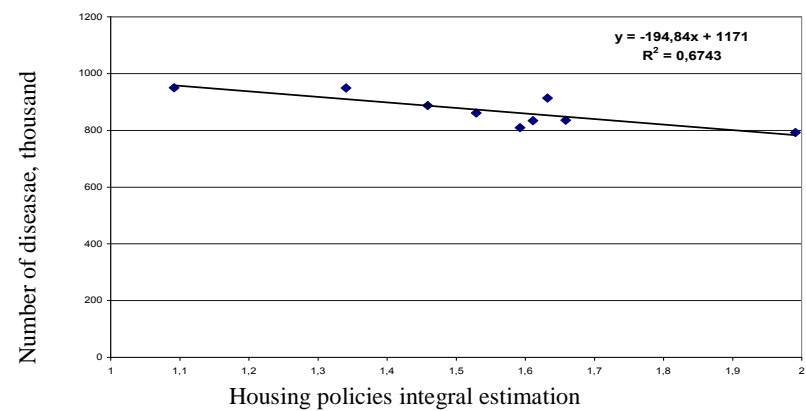

Fig. 5: Dependence of sickness amount on housing policies integral estimation
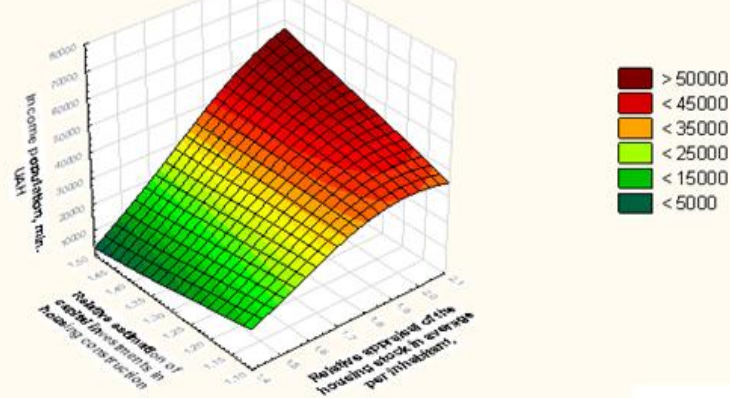

Fig. 6: Dependence of citizens incomes from relative indices of housing resources as averaged per capita and capital investment into housing construction.

Thus, dependence of economic and social spheres in the process of housing policies formation, which is a basis for defining an integral system list of indicators of evaluating region social and economic security, is revealed.

\section{Conclusion}

Housing policies formation should take into account transformational changes in the country's social and economic development and contribute to increase in the citizens' welfare.

It is proved that construction as one of the housing policies direction is one of the best economy multipliers. Specific aspects of housing construction include: constructing process various participants, constructing objects uniqueness; capital turnover relative slowness; high level of investment risk, which influence its organizing and construction market functioning.

Analysis of Poltava region housing policies in the directions of housing construction and reconstructing upon the main indicators is conducted, and peculiarities of their influence on the region social and economic security id revealed.

Modeling of housing policies influence on the region social and economic security is performed. Housing policies integral estimation is developed, and its connection with some of the main regional development social and economic indices is analyzed.

Correlational connections between the obtained region housing policies integral estimation and indices are defined, the main 
among which include: population incomes; population expenses for purchasing goods and services; population income differentiation R/P $10 \%$, proportion of population with lower monthly income per capita than enacted living wages, correlation between monetary income of the most and the least haves $10 \%$ of population, and number of sicknesses. Dependence between people income from relative indices such as housing resources in average per capita and capital investment into house building is defined.

\section{Acknowledgement}

The work is connected to the Poltava National Technical Yuri Kondratyuk University (Ukraine) Department of finances and banking scientific and research work - "Methodological foundation of region social and economic security provision" (Project ID: 0118U001096)

\section{References}

[1] Osypova I.I., Derzhavna sluzhba statystyky Ukrainy. Samootsinka domohospodarstvamy Ukrainy rivnia svoikh dokhodiv. Statystychnyi zbirnyk, 2017, pp. 9-12, available online: http://ukrstat.org/uk/druk/publicat/Arhiv_u/17/Arch_sdrd_zb.htm, last visit: 20.02 .2018 .

[2] Beer A., Thredgold Ch., Horne S. \& Charlier J., Public housing stock transfer - impacts and implications for local government: final report (2014), available online: http://apo.org.au/node/66345 //, last visit: 28.02.2018, doi: 10.4225/50/57D892FC27BBC

[3] Zayats T.\& Yanevych N., Evaluating of effectiveness of social investments financed from the budget of territorial communities, The Economic Annals-XXI, № 5-6(1), 2013, pp. 6-59, doi: https://doi.org/10.21003/ea.

[4] Trusova N. \& Klimenko, P., Building of socio-economic politics in the context of regional safety, Economic Annals-XXI. Vol. 157, № 3-4(1), 2016, pp. 38-40, doi: http://dx.doi.org/10.21003/ea.V157-0011

[5] Tinkova E. \& Tinkov S., Production potential development and quality of life of the population indicators modeling, Economic Annals-XXI, Vol. 157, № 3-4(1), 2016, pp.47-49, doi: http://dx.doi.org/10.21003/ea.V157-0014.

[6] Plagerson S. Can social protection address both poverty and inequality in principle and practice? Global Social Policy, 2016, available online: http://gsp.sagepub.com/content/early/2016/01/02/14680181156225 21, last visit: 20.02 .2018 . abstract doi: $10.1177 / 1468018115622521$.

[7] Ilyash O., The principles of state regulation in the sphere of socioeconomic security of Ukraine, The Economic Annals-XXI, № 7-8(1), 2014, pp. 24-28.

[8] Komelina O. \& Fursova N., Evaluation of social security: systemic and synergetic approach, The Economic Annals-XXI, № 7-8(1), 2014, pp. 12-15.

[9] Kharabara, V., Analysis of mortgage lending in banks in Ukraine. Baltic Journal of Economic Studies, Vol. 3, №3, 2017, pp. 59-63, doi: $10.30525 / 2256-0742$.

[10] Zavora T. \& Chepurny O., Forming the diagnostics methods of social security condition in a region, Economics \& Sociology, Vol. 7, № 1, 2014, pp. 228-248, doi: 10.14254/2071-789X.2014/7$1 / 20$.

[11] Onyshchenko V.O., Zavora T.M. \& Chepurnyi O.V., Sotsialna bezpeka rehionu: teoretychni ta prykladni aspekty: monohrafiia, Poltava: PoltNTU, 2015, 274 p.

[12] Onyshchenko V.O., Zavora T.M., Orhanizatsiino-ekonomichni zasady suchasnoi zhytlovoi polityky: rehionalnyi vymir: monohrafiia, Poltava: PoltNTU, 2012, 248 p.

[13] Xu Y., Mandatory savings, credit access and home ownership: The case of the housing provident fund, Urban Studies, Vol. 54, №15, 2017 pp.3446-3463, doi: 10.1177/0042098016676158.

[14] Paulo Nascimento Neto, Tomás Antonio Moreira, \& Zulma Das Graças Lucena Schussel, Housing Policy. A Critical Analysis on the Brazilian Experience. Mobility and Competitiveness, Vol 5, №³, 2012, pp 65-77.

[15] Osnovni pokaznyky sotsialno-ekonomichnoho rozvytku Ukrainy, available online: http://www.ukrstat.gov.ua, last visit: 28.01.2018

[16] Kalashnyk L. V., Statystychnyi shchorichnyk Poltavskoi oblasti za 2016 rik, Poltavskyi literator, 2017, pp. 80-86.
[17] Varnaliy Z., Onishchenko S. \& Masliy A., Threat prevention mechanisms of Ukraine's economic security, Economic AnnalsXXI, Vol. 159, №5-6, 2016, pp. 20-24, doi: http://dx.doi.org/10.21003/ea.V159-04.

[18] Thai Pham Huu Hong, Influence of Government spending on the house prices in Vietnam, Economic Annals-XXI, Vol. 162, № 1112, 2016, pp. 53-55, doi: https://doi.org/10.21003/ea.V162-11.

[19] Ferrero A., House price booms, current account deficits, and low interest rates. Journal of Money, Credit and Banking, 47(S1), (2015). pp. 261-293, doi: https://doi.org/10.1111/jmcb.12202.

[20] Johansen S., \& Juselius K., Maximum likelihood estimation and inference on cointegration - with applications to the demand for money, Oxford Bulletin of Economics and statistics, №52(2), 1990, pp. 169-210, doi: https://doi.org/10.1111/j.14680084.1990.mp52002003.x. 